\title{
A study on how organizational citizenship behavior influences on human resource management
}

\author{
Mostafa mahouti $^{\mathrm{a}^{*}}$, Masoumeh sadat Abtahi ${ }^{\mathrm{b}}$ and Ahmad sardari ${ }^{\mathrm{c}}$
}

${ }^{a}$ Department of Management, Qazvin Branch, Islamic Azad University, Qazvin, Iran

${ }^{b}$ Department of Humanities, Zanjan Branch, Islamic Azad University, Zanjan, Iran

${ }^{c}$ Department of Management, Shahed university, Tehran, Iran

\section{H R O N I C L E A B S T R A C T}

Article history:

Received July 28, 2013

Received in revised format

20 November 2013

Accepted 8 January 2014

Available online

January 112014

\section{Keywords:}

Organizational citizenship

behavior

Human resource management

Feasibility study

\begin{abstract}
During the past few years, there have been some evidences to believe that organizational citizenship behavior (OCB) could significantly influence on the success of organizations. This paper presents an empirical investigation to study the effects of OCB on human resource management. The proposed study designs a questionnaire and distributes it among some 260 experts who worked for an Iranian auto industry. The study designs a questionnaire in Likert scale, examines three hypotheses including the relationship between conscientiousness and information quality, courtesy and work efficiency and between civic virtue and work efficiency. Cronbach alphas for Courtesy, Civic virtue and Information Quality are calculated as $0.75,0.76$ and 0.81 , respectively. Using structural equation modeling, the study has confirmed existence of positive and meaningful relationships among various components of the survey, which confirms all three hypotheses of the survey.
\end{abstract}

\section{Introduction}

For years, there have been questions on what would be the best approach for service organizations to make an assessment on employees and how to improve their capabilities to retain existing customers and attract new customers (Morrison, 1996; Stamper \& Dyne, 2001; Bell \& Menguc, 2002; Organ, 2006). In addition, there were some interests on detecting necessary motivations to deliver high quality services. In fact, it is important to enable a service organization to formulate a system, which could build a link between human resource management policies and desired service employee performance, which helps organizations reach better financial outcomes. Bienstock et al. (2003) investigated organizational citizenship behavior (OCB), with its framework of organizational rights and responsibilities, to detect these issues. The study indicated that service employee perceptions of how they were treated by the service organization, were positively associated with organizational

*Corresponding author.

E-mail addresses: m_almasi2020@yahoo.com (M. Mahouti) 
citizenship behaviors. In addition, the study showed that these behaviors could result in more effective service delivery to organizational standards and enhanced customer perceptions of service quality.

Yoon and Suh (2003) investigated the relationships of employees' OCBs with job satisfaction, trust in manager, and customer's perceived service quality in travel agencies. The survey indicated that contact employees' job satisfaction and trust in manager were substantially associated with OCB and that their active engagement in OCB had a positive association with the perception of service quality. Donavan et al. (2006) applied the marketing concept in service firms through individual service employees and their interactions with customers. They reported that the positive influence of customer orientation on certain job responses seems to be stronger for service workers who spend more time in direct contact with customers than for workers who spend less time with customers.

Walumbwa et al. (2010) examined the effect of servant leadership on two group climates, employee attitudes, and OCB. Their empirical investigation indicated that commitment to the supervisor, selfefficacy, procedural justice climate, and service climate partially mediated the relationship between servant leadership and OCB. They also reported that procedural justice climate and positive service climate amplified the impact of commitment to the supervisor on organizational citizenship behavior. Konovsky and Pugh (1994) investigated a social exchange model of OCB by proposing an employee's trust in a supervisor to mediate the relationship between procedural fairness in the supervisor's decision making and employee citizenship. Dimitriades (2007) investigated the influence of service climate and job involvement on customer-oriented organizational citizenship behavior in Greek service organizations. They reported that the concept of customer-oriented OCB was a useful construct in the Greek context.

Podsakoff et al. (1997) performed another survey and reported that helping behavior and sportsmanship had substantial impacts on performance quantity and that helping behavior had an important effect on performance quality. However, the study did not find any relationship between civic virtue and performance measure. Podsakoff et al. (2009) provided a meta-analytic examination of the relationships between OCBs and different individual as well as organizational-level outcomes. Their results indicated that OCBs were associated with a number of individual-level outcomes, including managerial ratings of employee performance, reward allocation decisions, etc. Besides, OCBs were detected to be associated with a number of organizational-level outcomes including productivity, efficiency, reduced costs, customer satisfaction, and unit-level turnover. They also reported some stronger relationships between OCBs and unit-level performance measures providing some evidence that OCBs were associated with these criteria.

\section{The proposed study}

For many years, researchers were interested in investigating the relationship between organizational citizenship behavior (OCB) and organizations performance. In this paper, we present an empirical investigation to study the effects of OCB on human resource management. The proposed study designs a questionnaire and distributes it among some 260 experts who worked for auto industry. The study designs a questionnaire in Likert scale, examines three hypotheses as follows,

1. There is a relationship between conscientiousness and information quality.

2. There is a relationship between courtesy and work efficiency.

3. There is a relationship between civic virtue and work efficiency.

The proposed study uses structural equation modeling to examine different hypotheses of the survey. Cronbach alphas for Courtesy, Civic virtue and Information Quality are calculated as 0.75, 0.76 and 0.81 , respectively. Table 1 demonstrates the results of factor analysis. 
Table 1

The summary of factor analysis

\begin{tabular}{|c|c|c|c|c|c|c|c|c|}
\hline Construct & 1 & 2 & 3 & 4 & 5 & 6 & 7 & 8 \\
\hline \multicolumn{9}{|l|}{ Courtesy } \\
\hline Q9 & & & $0.51^{*}$ & & & & & \\
\hline Q10 & & & $0.53^{*}$ & & & & & \\
\hline Q11 & & & $0.50^{*}$ & & & & & \\
\hline \multicolumn{9}{|c|}{ Civic virtue } \\
\hline Q12 & & & & $0.55^{*}$ & & & & \\
\hline Q13 & & & & $0.46^{*}$ & & & & \\
\hline Q14 & & & & $0.54^{*}$ & & & & \\
\hline Q15 & & & & $0.53^{*}$ & & & & \\
\hline \multicolumn{9}{|c|}{ Sportsmanship } \\
\hline Q16 & & & & & $0.52^{*}$ & & & \\
\hline Q17 & & & & & $0.50^{*}$ & & & \\
\hline Q18 & & & & & $0.53^{*}$ & & & \\
\hline Q19 & & & & & $0.83^{*}$ & & & \\
\hline \multicolumn{9}{|c|}{ Information Quality } \\
\hline Q20 & & & & & & $0.53^{*}$ & & \\
\hline Q21 & & & & & & $0.55^{*}$ & & \\
\hline Q22 & & & & & & $0.63^{*}$ & & \\
\hline Q23 & & & & & & $0.56^{*}$ & & \\
\hline Q24 & & & & & & $0.54^{*}$ & & \\
\hline
\end{tabular}

Next, we present details of our findings on testing three hypotheses of the survey.

\section{The results}

In this section, we present details of our findings on testing various hypotheses of the survey.

\subsection{The first hypothesis: The relationship between conscientiousness and information quality}

The first hypothesis of the survey investigates the relationship between conscientiousness and information quality. The implementation of path analysis yields a positive impact from conscientiousness towards information quality $(\beta=0.49$, t-value $=13.76$, sig $<0.05)$ when the level of significance is five percent. Therefore, the first hypothesis of the survey has been confirmed.

\subsection{The second hypothesis: The relationship between courtesy and work efficiency}

The first hypothesis of the survey investigates the relationship between courtesy and work efficiency. The implementation of path analysis yields a positive impact from courtesy towards work efficiency $(\beta=0.50, t-v a l u e=8.50$, sig $<0.05)$ when the level of significance is five percent, which confirms the second hypothesis of the survey.

\subsection{The third hypothesis: The relationship between civic virtue and work efficiency}

The last hypothesis of the survey investigates the relationship between civic virtue and work efficiency. The implementation of path analysis yields a positive impact from civic virtue towards work efficiency $(\beta=0.68$, t-value $=6.68, \operatorname{sig}<0.05)$ when the level of significance is five percent, which confirms the third hypothesis of the survey. 


\section{Conclusion}

In this paper, we have presented an empirical investigation to study the effects of organization citizenship behavior on human resources management. The proposed study has considered the effects of conscientiousness, courtesy and civic virtue on information quality as well as work efficiency. The proposed study has been implemented among different employees who worked for an Iranian automaker. The result of the survey has confirmed that there was a meaningful relationship between conscientiousness and information quality. This means that people with good discipline feel more responsible on accomplishing their tasks and performing good quality duties. The survey also concluded that there was a meaningful relationship between courtesy and work efficiency, which means people with good behaviors, may contribute more on firm. Finally, the survey has reported that there was a positive impact from civic virtue towards work efficiency.

\section{Acknowledgement}

The authors would like to thank the anonymous referees for constructive comments on earlier version of this paper. We are also delighted for the support of an Iranian automaker.

\section{References}

Bell, S. J., \& Menguc, B. (2002). The employee-organization relationship, organizational citizenship behaviors, and superior service quality. Journal of retailing, 78(2), 131-146.

Bienstock, C. C., DeMoranville, C. W., \& Smith, R. K. (2003). Organizational citizenship behavior and service quality. journal of services marketing, 17(4), 357-378.

Dimitriades, Z. S. (2007). The influence of service climate and job involvement on customer-oriented organizational citizenship behavior in Greek service organizations: a survey. Employee Relations, 29(5), 469-491.

Donavan, D. T., Brown, T. J., \& Mowen, J. C. (2004). Internal benefits of service-worker customer orientation: job satisfaction, commitment, and organizational citizenship behaviors. Journal of marketing, 68(1), 128-146.

Konovsky, M. A., \& Pugh, S. D. (1994). Citizenship behavior and social exchange. Academy of management journal, 37(3), 656-669.

Morrison, E. W. (1996). Organizational citizenship behavior as a critical link between HRM practices and service quality. Human Resource Management, 35(4), 493-512.

Podsakoff, P. M., Ahearne, M., \& MacKenzie, S. B. (1997). Organizational citizenship behavior and the quantity and quality of work group performance. Journal of applied psychology, 82(2), 262270.

Podsakoff, N. P., Whiting, S. W., Podsakoff, P. M., \& Blume, B. D. (2009). Individual-and organizational-level consequences of organizational citizenship behaviors: A metaanalysis. Journal of Applied Psychology, 94(1), 122-141.

Organ, D. W., Podsakoff, P. M., \& MacKenzie, S. B. (2006). Organizational citizenship behavior: Its nature, antecedents, and consequences. Sage.

Stamper, C. L., \& Dyne, L. V. (2001). Work status and organizational citizenship behavior: A field study of restaurant employees. Journal of Organizational Behavior, 22(5), 517-536.

Yoon, M. H., \& Suh, J. (2003). Organizational citizenship behaviors and service quality as external effectiveness of contact employees. Journal of Business Research, 56(8), 597-611.

Walumbwa, F. O., Hartnell, C. A., \& Oke, A. (2010). Servant leadership, procedural justice climate, service climate, employee attitudes, and organizational citizenship behavior: a cross-level investigation. Journal of Applied Psychology, 95(3), 517. 